Article

\title{
Characteristics of Pollutants and Microbial Communities Obtained in Simulated Lysimeters of Swine Carcasses
}

\author{
Jae-Min Choi ${ }^{1}$, Sun-Kee Han ${ }^{2}$ and Chae-Young Lee ${ }^{1,3, *}$ \\ 1 Department of Civil Engineering, The University of Suwon, 17, Wauan-gil, Hwaseong-si, \\ Gyeonggi-do 18323, Korea; jaeminch@suwon.ac.kr \\ 2 Department of Environmental Health, Korea National Open University, 86, Daehak-ro, Jongno-gu, \\ Seoul 03087, Korea; skhan003@knou.ac.kr \\ 3 Institute of River Environmental Technology, 17, Wauan-gil, Hwaseong-si, Gyeonggi-do 18323, Korea \\ * Correspondence: chaeyoung@suwon.ac.kr; Tel.: +82-31-220-2470
}

Academic Editors: Geonha Kim, Daniel C.W. Tsang, Zeng-Yei Hseu and Meththika Vithanage Received: 30 December 2016; Accepted: 15 March 2017; Published: 21 March 2017

\begin{abstract}
This study was performed to investigate the characteristics of pollutants and microbial communities obtained in simulated lysimeters and to evaluate the effects of anaerobic sludge and water on the biodegradation of swine carcasses. The leachate production rates of Lysimeters 2 and 3 with the addition of anaerobic sludge were higher than that of Lysimeter 1 (control). The methane production rate of Lysimeter 3 with anaerobic sludge addition and increased water content was higher than those of other lysimeters. The result of microbial community analysis revealed that the relative abundances of Proteobacteria including pathogens in Lysimeter 3 were lower than those in other lysimeters. Overall, this study demonstrated that the proper operating conditions of lysimeters accelerated the stabilization of swine carcasses and could contribute to sustainable land use.
\end{abstract}

Keywords: biodegradation; lysimeters; anaerobic sludge; water content; swine carcass

\section{Introduction}

The outbreak of foot and mouth disease (FMD) in South Korea in 2010 led to approximately 3.4 million livestock carcasses and over 4500 burial sites [1]. FMD mainly appears in even-toed hoofed mammals (Artiodactyla), also known as cloven-hoofed mammals, such as swine and cattle. It is classified as a List A disease by the Office International des Epizooties (OIE) because its communicability is very high $[2,3]$.

Disposal methods of livestock carcasses with infectious diseases include burial, incineration, rendering, and composting. Although livestock burial may lead to environmental contamination including ground and surface water with pathogens and infective agents [4], it has the advantage of enabling the disposal of a large number of livestock carcasses in a short time [5]. Thus, livestock burial is still used in some regions and countries.

Biodegradation of livestock carcasses in burial sites has been influenced by various factors such as temperature, water content, microbial communities, and species of livestock carcasses [4]. Livestock carcasses are biodegraded under anaerobic conditions. The leachate produced from the burial sites contains relatively high concentrations of contaminants compared to groundwater and has been reported to be a potential cause of contamination of soil and groundwater [6-9]. The gas generated from burial sites consists of mainly of methane and carbon dioxide, and its contents are affected by seed microorganisms [10]. 
A few studies about livestock carcass burial sites have examined the characteristics of leachate, but there have been very few studies about the evaluation of the atmospheric environmental impacts from livestock carcass burial sites. To investigate the characteristics of livestock carcass biodegradation in burial sites under anaerobic condition, both the leachate and gas produced from burial sites should be considered [6-12].

Previous studies have presented results on the characteristics of pollutants such as leachate and gas, and reported that they could adversely affect the environment. There are few studies on the operating plan to reduce the impact of livestock burial on the environment and to enhance land use.

This study was, therefore, performed to examine the characteristics of leachate and gas produced from livestock carcass burial sites using simulated lysimeters under different operating conditions. The effects of the addition of anaerobic sludge and water on leachate and gas production were evaluated and the pyrosequencing microbial techniques were used to reveal the microbial communities of all lysimeters.

\section{Materials and Methods}

\subsection{Materials}

In this study, swine carcasses were used as substrates and were kept at $-20{ }^{\circ} \mathrm{C}$ to prevent decomposition until use. The total solids (TS), volatiles solids (VS) and total organic carbon (TOC) of swine carcasses were $0.26 \mathrm{~g}$ TS $/ \mathrm{g}, 0.25 \mathrm{~g}$ VS/g and $334.0 \mathrm{~g}$ TOC $/ \mathrm{kg} \mathrm{VS}$, respectively. The seed sludge was obtained from an anaerobic digester in a local wastewater treatment plant in $\mathrm{H}$ city. The $\mathrm{pH}$, alkalinity, and volatile solids (VS) of the sludge were 6.9, $2.3 \mathrm{~g} / \mathrm{L}$ as $\mathrm{CaCO}_{3}$, and $19.0 \mathrm{~g} / \mathrm{L}$, respectively.

\subsection{Lysimeter Operation}

All three lysimeters were made in a 1/1000 scale of the standard burial sites presented by the South Korean Ministry of Agriculture, Food, and Rural Affairs (Figure 1) and then placed inside a container. Gravel was placed at the bottom of lysimeters to prevent clogging of sampling ports for leachate. The fine-textured soil without sterilization was used for backfilling of lysimeters and compacted with a tapping machine. The compaction density and void ratio of the lower cover soil $(0.1 \mathrm{~m})$ were $1.6 \mathrm{~g} / \mathrm{cm}^{3}$ and 0.8 , respectively. Then, approximately $30 \mathrm{~kg}$ of swine carcasses (five heads) without grinding was placed on the backfilled soil. The seed sludge and deionized water according to the operating conditions (Table 1) were added to the carcass layers of lysimeters to investigate its influence on the degradation of livestock carcasses. The water content of the seed sludge was considered when it was simultaneously added into lysimeters with water. The upper cover soil $(0.2 \mathrm{~m})$ was filled with the fine-textured soil without compaction. The thermometers were equipped in livestock carcass layers. The temperature was not controlled [13].

Table 1. Operating conditions of lysimeters.

\begin{tabular}{cccc}
\hline Parameters & Lysimeter 1 & Lysimeter 2 & Lysimeter 3 \\
\hline Substrate & \multicolumn{3}{c}{ Swine Carcasses (5 Heads) } \\
\hline Water content $(\%, \mathrm{v} / \mathrm{v})$ & $30 \%$ & $30 \%$ & $40 \%$ \\
Anaerobic sludge $(\%, \mathrm{w} / \mathrm{w})$ & $\times$ & 0.04 & 0.04 \\
\hline
\end{tabular}




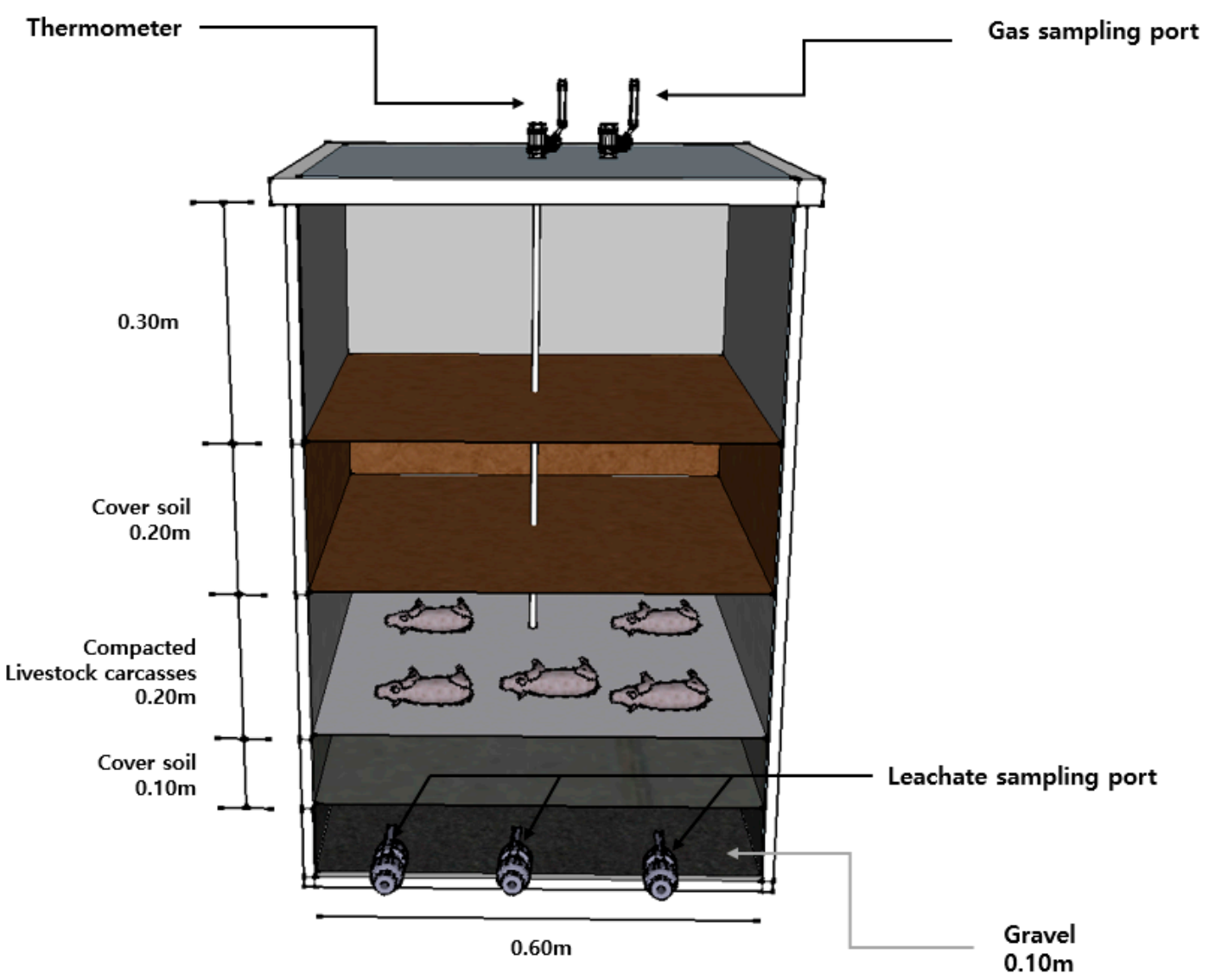

Figure 1. Schematic diagram of the lysimeter.

\subsection{Analytical Methods}

The leachate samples were either measured on site or stored at $4{ }^{\circ} \mathrm{C}$ until analysis. The $\mathrm{pH}$ of leachate was immediately analyzed on site using a pH meter (YSI 556 MPS, YSI, Yellow Springs, OH, USA). The concentrations of biochemical oxygen demand (BOD), chemical oxygen demand (COD) and ammonia-N $\left(\mathrm{NH}_{4}{ }^{+}-\mathrm{N}\right)$ were measured according to Standard Methods [14]. Total kjeldahl nitrogen (TKN) concentration was analyzed using a Kjetec system (KjetecTM 8100, Foss, Hillerød, Denmark) and total organic carbon (TOC) concentration was measured with a TOC analyzer (TOC-VCPH, Shimadzu, Kyoto, Japan). The gas composition was analyzed using a gas chromatography system (GC, Gow Mac series 580, GOW-MAC Instrument Co., Bethlehem, PA, USA) equipped with a thermal conductivity detector (TCD) and $6 \mathrm{ft} \times 2 \mathrm{~mm}$ (i.d.) stainless steel Porapak Q (80/100 mesh) column. The operating temperatures of the injector, detector and column were kept at 90,80 , and $50{ }^{\circ} \mathrm{C}$, respectively. In addition, high purity (99.999\%) helium gas was used as a carrier gas. The produced gas was adjusted to the standard temperature and pressure (STP).

Cumulative leachate and methane production curves were described by the following modified Gompertz Equation [15]:

$$
\mathrm{M}=\mathrm{P} \cdot \exp \left[-\exp \left\{\frac{\mathrm{R}_{\mathrm{m}} \cdot \mathrm{e}}{\mathrm{P}}(\lambda-\mathrm{t})+1\right\}\right]
$$

where, $\mathrm{M}=$ cumulative production $(\mathrm{L} / \mathrm{kg} \mathrm{VS}) ; \mathrm{P}=$ maximum production $(\mathrm{L} / \mathrm{kg} \mathrm{VS}) ; \mathrm{R}_{\mathrm{m}}=$ maximum production rate $(\mathrm{L} / \mathrm{kg}$ VS-d); $\lambda=$ lag phase $(\mathrm{d}) ; \mathrm{t}=$ time $(\mathrm{d}) ;$ an $\mathrm{e}=\exp (1)$. 


\subsection{Microbial Analysis}

Bacteria and archaea communities were characterized using next generation sequencing (454 pyrosequencing). The samples were collected on Day 382 and were stored at $4{ }^{\circ} \mathrm{C}$ prior to the analysis. The total genomic DNA was extracted from the sample by using the Mobio PowerSoil DNA extraction kit (Solana Beach, CA, USA). 16S rRNA genes fragments were amplified from the obtained DNA using a primer set, 27F (5'-AGAGTTGATCCTGGCTCAG-3') and 518R (5'-ATTTACCGCGGGCTGCTGG-3') for bacteria and 344F (5'-ACGGGGCTGCAGCAGGGGCGA-3') and 915R (5'-GTGCTCCCCCGCCAATTCCT-3') for archaea. The 454 pyrosequencing of the PCR amplicons was conducted by Macrogen Inc. (Seoul, Korea) for sequencing on the Roche GS FLX 454 pyrosequencing platform to generate 400 -bp sequence reads. The raw sequence reads were sorted, purified, trimmed, qualified and clustered to operational taxonomic units (OTUs). Then, taxonomic classification of the refined sequence was performed using the RDP's Classifier (http:/ / pyro.cme.msu. edu/). Detailed PCR conditions, pyrosequencing, and phylogenic analysis are described in previous publication $[16,17]$.

\section{Results and Discussion}

\subsection{Characteristics of Leachate Production}

Figure 2 illustrates that the total cumulative leachate production of Lysimeters 1, 2 and 3 were $1.7,2.7$ and $3.0 \mathrm{~L} / \mathrm{kg} \mathrm{VS}$, respectively, due to the difference of operating conditions (i.e., anaerobic sludge addition and initial water content). The volume of leachate produced from livestock carcasses was calculated by excluding the volume of water injected initially from the total volume of leachate. Leachates were continuously produced from Lysimeters 1, 2 and 3 for 70 days and, thereafter, were shown to be insignificant. The maximum leachate production rates of Lysimeters 1, 2 and 3 were 0.04, 0.08 and $0.09 \mathrm{~L} / \mathrm{kg}$ VS-d, respectively. Lysimeters 2 and 3 with the addition of anaerobic sludge showed similar maximum leachate production rates, while Lysimeter 1 without it showed a lower one. The previous studies reported that leachate production was affected by water content, climate and biodegradation of organic matter. The leachate production of lysimeter with increased water content by rainfall was higher than that of the control. Both microorganism addition and increased water content led to acceleration of biodegradation of organic matter [18-20]. In this study, the total leachate production in Lysimeter 3 was found to be higher than any other lysimeter due to increased water content. The leachate production rates of Lysimeters 2 and 3 with the addition of anaerobic sludge were higher than that of Lysimeter 1 without it.

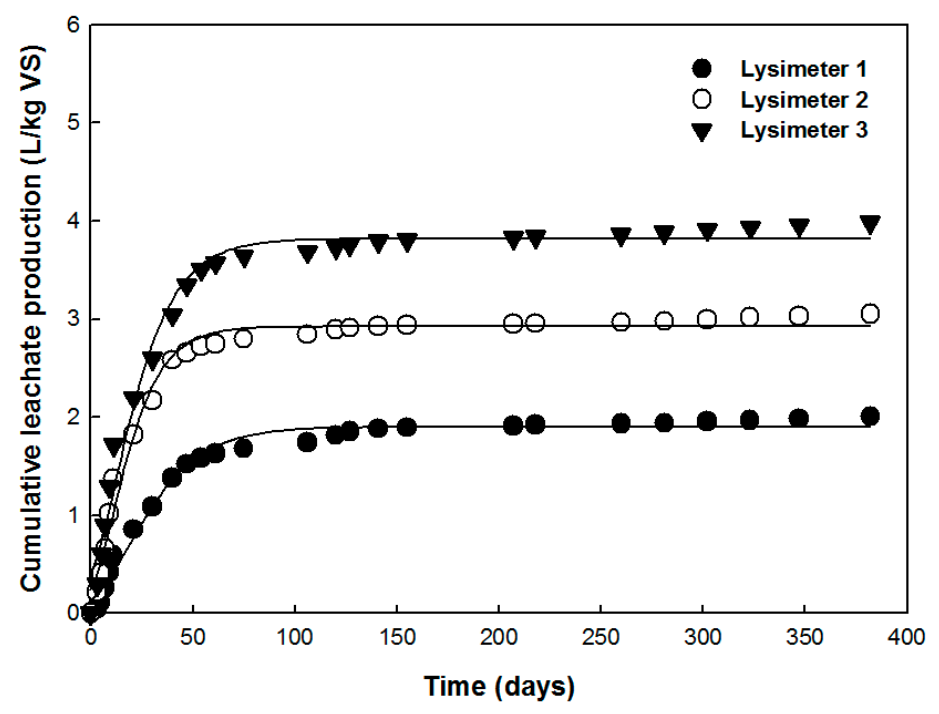

Figure 2. Cumulative leachate production of Lysimeters 1, 2 and 3. 
Table 2 shows that the characteristics of the leachates produced from Lysimeters 1, 2 and 3. The COD, BOD, and TOC concentrations, related to organic matter, in the leachate produced from Lysimeter 1 were 965-88,980, 858-77,089, and 513-36,864 mg/L, respectively. Lysimeters 2 and 3 showed lower concentrations compared to Lysimeter 1. Tatsi and Zoubloulis (2002) reported that increased water volume during the wet season caused a larger volume of diluted leachate, whereas the concentration of pollution parameters was higher during dry season [21]. This study revealed that the lower concentration of pollutants from Lysimeter 3 was due to a larger volume of leachate and that the higher concentration of pollutants from Lysimeter 1 was caused by a smaller volume of leachate. However, the $\mathrm{NH}_{4}{ }^{+}$in leachate from Lysimeter 3, on a mass basis, was $9.2 \mathrm{~g}$, which was higher than that $(7.3 \mathrm{~g})$ in leachate from Lysimeter 1 . Lysimeter 3 resulted in a higher release of $\mathrm{NH}_{4}{ }^{+}$due to the proper operating conditions.

Table 2. Characteristics of leachates produced from Lysimeters 1, 2 and 3.

\begin{tabular}{|c|c|c|c|c|c|c|c|c|c|}
\hline \multirow{2}{*}{ Item } & \multicolumn{3}{|c|}{ Lysimeter 1} & \multicolumn{3}{|c|}{ Lysimeter 2} & \multicolumn{3}{|c|}{ Lysimeter 3} \\
\hline & Min. & Max. & Avg. & Min. & Max. & Avg. & Min. & Max. & Avg. \\
\hline $\mathrm{pH}$ & 6.1 & 8.3 & $7.5 \pm 0.7$ & 6.1 & 8.5 & $7.6 \pm 0.8$ & 6.2 & 8.8 & $7.8 \pm 0.9$ \\
\hline TS (mg/L) & 5970 & 31,150 & $20,868 \pm 8654.5$ & 3580 & 15,480 & $8837 \pm 4471.3$ & 1380 & 12,610 & $7311 \pm 3217.2$ \\
\hline VS (mg/L) & 3160 & 22,550 & $15,320 \pm 6321.4$ & 1770 & 10,290 & $5167 \pm 3541.2$ & 500 & 8190 & $4383 \pm 2477.3$ \\
\hline $\mathrm{COD}(\mathrm{mg} / \mathrm{L})$ & 965 & 88,980 & $45,611 \pm 19,831.5$ & 953 & 38,651 & $21,301 \pm 9675.5$ & 813 & 32,492 & $20,092 \pm 8280.7$ \\
\hline $\mathrm{BOD}(\mathrm{mg} / \mathrm{L})$ & 858 & 77,089 & $27,960 \pm 17,230.9$ & 811 & 30,904 & $11,359 \pm 7165.6$ & 617 & 18,615 & $8537 \pm 4912.4$ \\
\hline TOC (mg/L) & 513 & 36,864 & $12,827 \pm 8489.5$ & 487 & 14,749 & $5456 \pm 4203.5$ & 413 & 12,096 & $3789 \pm 2753.5$ \\
\hline BOD/COD & 0.38 & 0.89 & $0.62 \pm 0.16$ & 0.23 & 0.85 & $0.55 \pm 0.19$ & 0.10 & 0.76 & $0.43 \pm 0.19$ \\
\hline TOC/COD & 0.13 & 0.60 & $0.31 \pm 0.15$ & 0.09 & 0.77 & $0.31 \pm 0.21$ & 0.07 & 0.61 & $0.23 \pm 0.18$ \\
\hline TKN (mg/L) & 1051 & 2541 & $1831 \pm 506.4$ & 851 & 2002 & $1337 \pm 429.9$ & 441 & 1751 & $1025 \pm 427.6$ \\
\hline $\mathrm{NH}_{4}{ }^{+}-\mathrm{N}(\mathrm{mg} / \mathrm{L})$ & 515 & 983 & $802 \pm 138.3$ & 422 & 917 & $645.1 \pm 156.8$ & 244 & 802 & $493 \pm 166.1$ \\
\hline
\end{tabular}

Previous studies reported that it would be more effective to use appropriate ratios between the different parameters instead of absolute values because the concentrations of contaminants varied widely $[21,22]$. Due to the generation of refractory matter such as humic substances or non-biodegradable matter, the $\mathrm{BOD} / \mathrm{COD}$ ratio decreases as the biodegradation of organic matter proceeds [23]. Tatsi and Zoublis (2002) reported that the ranges of COD and BOD of landfill leachate were $44,000-115,000$ and $9500-80,795 \mathrm{mg} / \mathrm{L}$, respectively, and the BOD/COD ratio of the leachate decreased from 0.97 to 0.14 as organic matter was degraded. In this study, the BOD/COD ratio in Lysimeter 1 decreased from 0.89 to 0.38 , while the BOD/COD ratio in Lysimeter 3 decreased from 0.76 to 0.10 . The VS/TS ratios of the leachates in Lysimeters 1,2 and 3 were $0.54,0.48$ and 0.35 , respectively. As results of previous studies, the range of VS/TS ratio was 0.21 to 0.66 , which was similar to this study. The VS/TS ratio of leachate from stabilized landfill ranged from 0.21 to 0.37 [10,21]. In comparison to previous studies, the leachate of Lysimeter 3 reached the stabilization phase.

The burial sites are an unfavorable condition for carcass decomposition [24]. The soil with a low water content promotes desiccation and can result in decreased the biodegradation of carcasses. The activity of hydrolytic enzymes and/or microorganisms associated with cycling of carbon and nutrients can be decreased by low water content $[24,25]$. The Lysimeter 3 in this study has a favorable conditions for the biodegradation of livestock carcasses compared to the natural soil. Therefore, the waiting time for land reuse may be shortened due to the biodegradation of livestock carcasses being, accelerated.

\subsection{Characteristics of Gas Production}

Figure 3 illustrates methane produced from Lysimeters 1,2 and 3. In the first 106 days, cumulative methane production in Lysimeters 1, 2, and 3 showed a continuously increasing tendency. From Day 107 to Day 206, cumulative methane production in all three lysimeters was relatively constant. The soil temperature was $25^{\circ} \mathrm{C}$ in the first 75 days, and then it decreased to $2{ }^{\circ} \mathrm{C}$ until Day 260 (Figure 4). 


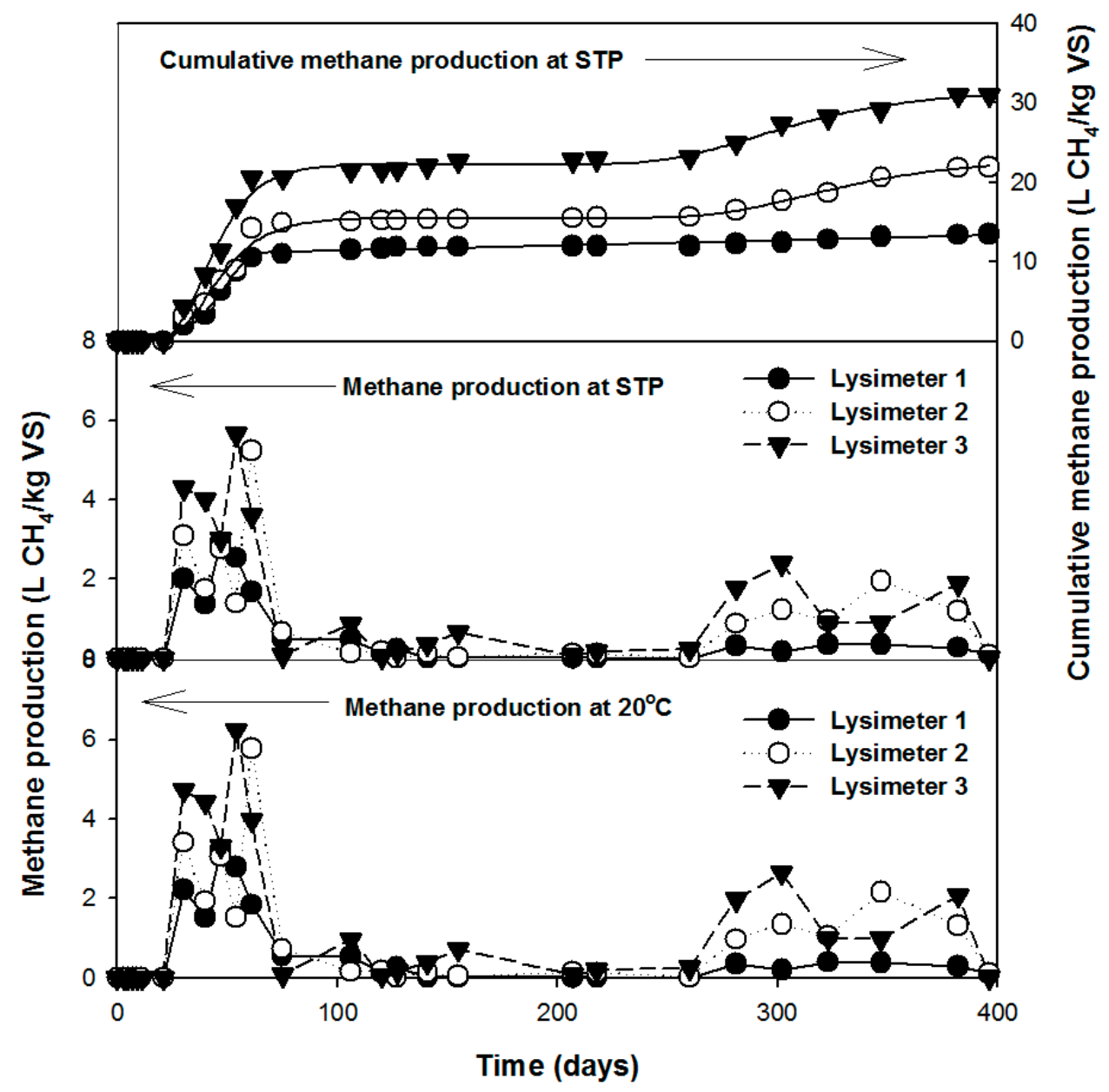

Figure 3. Methane production of Lysimeters 1, 2 and 3 with time.

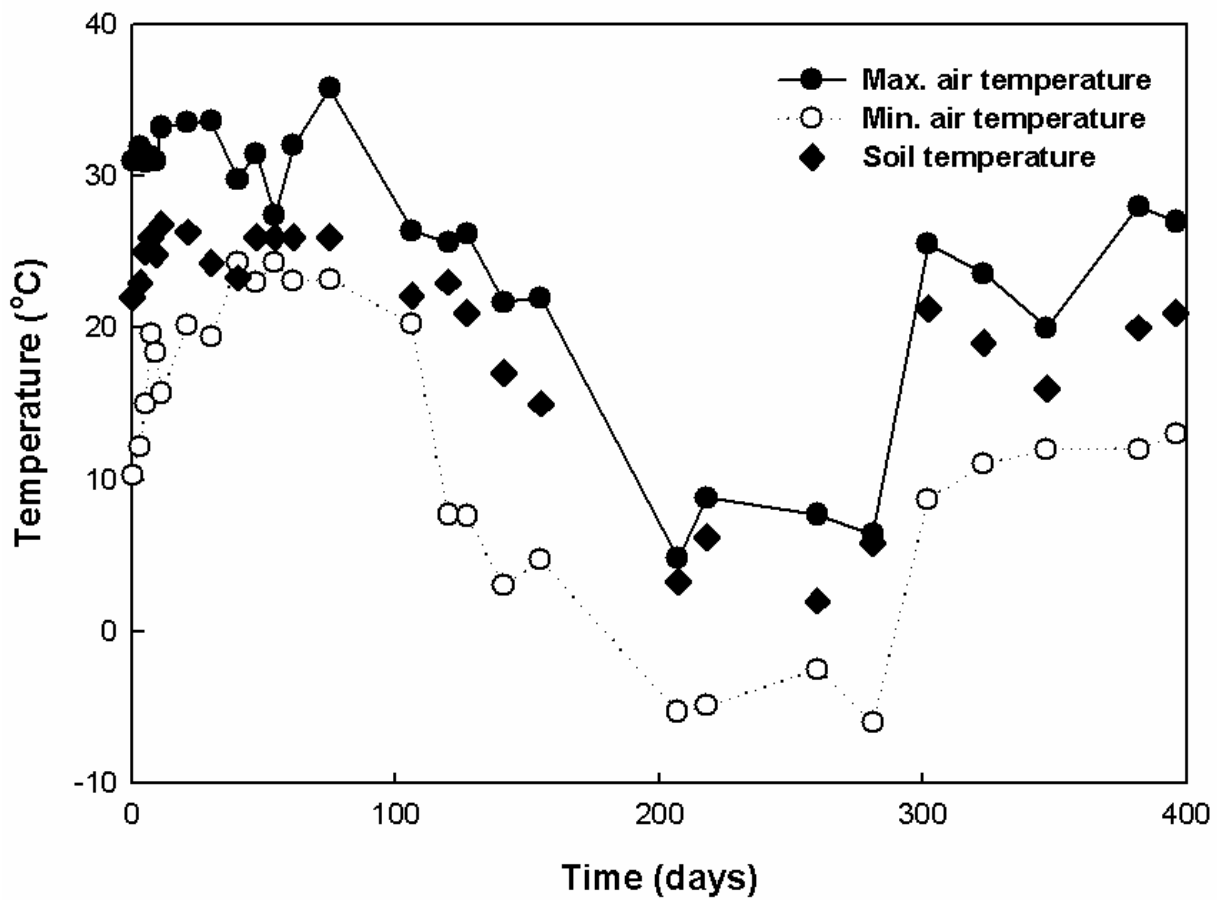

Figure 4. Variation of temperature in air and soil with time. 
The maximum methane production of Lysimeters 1, 2, and 3 were 13.5, 21.9 and $31.0 \mathrm{~L} \mathrm{CH}_{4} / \mathrm{kg}$ VS, respectively. In the first 260 days, the maximum methane production rates of Lysimeters 1, 2 and 3 were $0.36,0.41$ and $0.64 \mathrm{~L} \mathrm{CH}_{4} / \mathrm{kg}$ VS-d, respectively. Thereafter, the maximum methane production rates of Lysimeters 1, 2 and 3 were $0.01,0.05$ and $0.09 \mathrm{~L} \mathrm{CH}_{4} / \mathrm{kg}$ VS-d, respectively.

Khanal (2008) reported that temperature has a significant effect on the methane production rate [26]. The activity of methanogens at $25^{\circ} \mathrm{C}$ and $5{ }^{\circ} \mathrm{C}$ showed $41 \%$ and $93 \%$, compared to that of methanogens at $30^{\circ} \mathrm{C}$, respectively. Therefore, the methane production shown from Day 107 to Day 260 was caused by the decrease of the activity of methanogens due to temperature. Yuan et al. (2012) evaluated the methane production characteristics of cattle carcasses through anaerobic digestion [9]. According to the results, the methane production of a reactor with the addition of anaerobic sludge increased 1.8 times more than that of the control. Christensen et al. (1989) reported that the additional supply of water and microorganisms increased gas production in landfills [20]. In this study, the methane production of Lysimeters 2 and 3 with the addition of anaerobic sludge increased 1.6 and 2.3 times more than that of Lysimeter 1, respectively. Moreover, the methane production of Lysimeter 3 increased 1.4 times more than that of Lysimeter 2.

\subsection{Comparison of the Leachate and Gas Production Characteristics}

In the first 106 days, though the leachate production rate of Lysimeter 2 was two times higher than that of Lysimeter 1, the methane production rates of Lysimeters 1 and 2 were similar to each other. Furthermore, the leachate production rates of Lysimeters 2 and 3 were similar to each other, but the methane production rate of Lysimeter 3 was 1.6 times higher than that of Lysimeter 2.

The rate constants of COD were predicted by first order kinetics [27]. The hydrolysis constants (k) of Lysimeters 1, 2 and 3 were $-0.0013,-0.0020$ and $-0.0023 \mathrm{~d}^{-1}$, respectively (Figure 5).

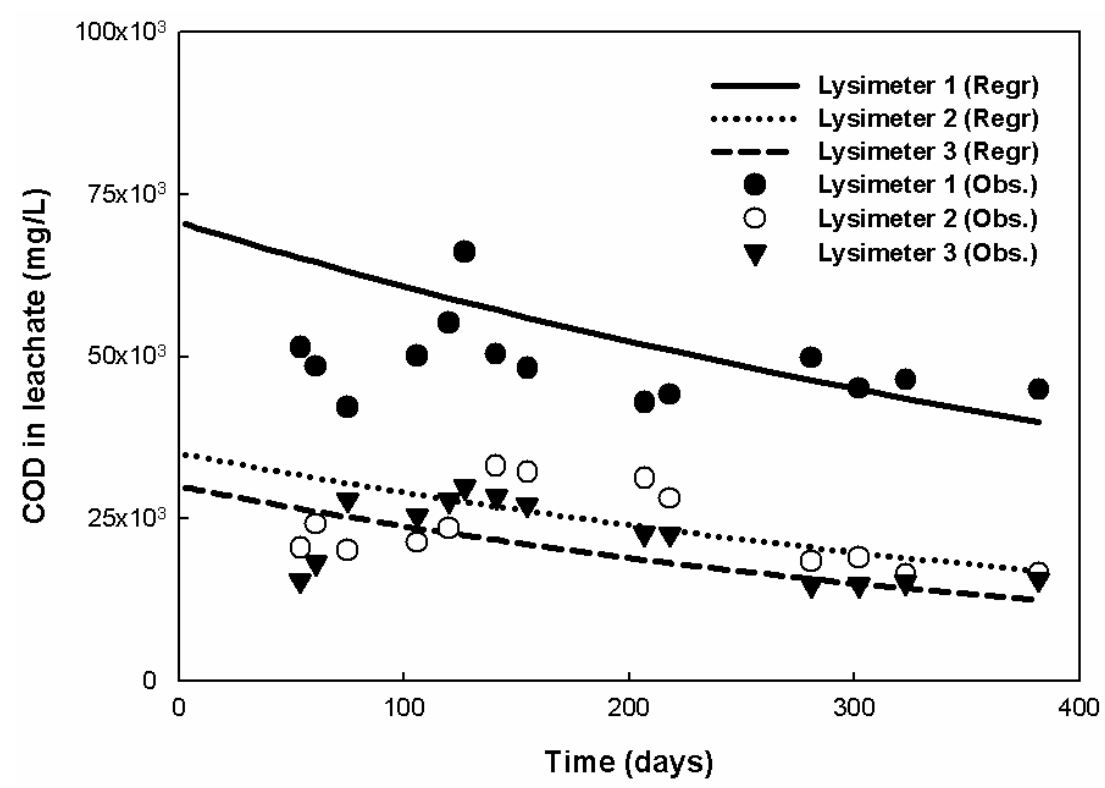

Figure 5. Behaviors of COD concentrations in leachates produced from Lysimeters 1, 2, and 3 with time.

According to previous studies, the decay constant of organic matters in landfill with a seed microorganism was $0.033 \mathrm{yr}^{-1}$, which was 1.9 times higher than that $\left(0.016 \mathrm{yr}^{-1}\right)$ without it $[28,29]$. $\mathrm{Li}$ et al. (2014) reported that a methane production rate increased 1.3 times with increased water content from $70 \%$ to $75 \%$ in dry anaerobic digestion [30]. The results of this study and previous studies indicated that anaerobic sludge addition affected a hydrolysis constant and a maximum leachate production rate, but did not have a significant effect on a maximum methane production rate. However, both anaerobic sludge addition and increased water content influenced the maximum 
leachate and methane production rates. Fujishima et al. (1999) observed that methane production decreased from 330 to $290 \mathrm{~mL} \mathrm{CH}_{4} / \mathrm{g} \mathrm{VSS}_{\text {added }}$ when water content decreased from $92.9 \%$ to $89.0 \%$, and found that acetoclastic methanogens had resistance to high ammonia concentration (750 4400 $\mathrm{mg} \mathrm{N} / \mathrm{L}$ ) whereas hydrogenotrophic methanogens were inhibited by it [31]. Therefore, the maximum methane production of Lysimeter 3 was higher than those of other lysimeters due to anaerobic sludge addition and increased water content.

The degradation efficiencies of livestock carcasses in all three lysimeters were evaluated based on TOC balance (Figure 6). The efficiency of degradation was calculated as degradation efficiency $=($ TOC of leachate and gas $) /($ initial TOC of carcasses $) \times 100$. The cumulative amount of TOC (leachates and gases) of Lysimeters 1, 2 and 3 were 62.1, 85.5 and $107.9 \mathrm{~g}$ TOC $/ \mathrm{kg} \mathrm{VS}$, respectively. The degradation efficiencies were calculated as (TOC of leachate and gas)/(initial TOC of carcasses) $\times 100$. The cumulative amount of TOC (leachates and gases) of Lysimeters 1, 2 and 3 were $62.1,85.5$ and $107.9 \mathrm{~g}$ TOC $/ \mathrm{kg}$ VS, respectively. The degradation efficiencies of Lysimeters 1, 2 and 3 were $18.6 \%$ (leachate: $13.8 \%$; gas: $4.8 \%$ ), $25.6 \%$ (leachate: $19.2 \%$; gas: $6.4 \%$ ) and $32.3 \%$ (leachate: $23.8 \%$; gas: $8.5 \%$ ), respectively. Matsufuji et al. (2014) reported that the amount of carbon released by leachate from initial landfill was high, which was similar to the result of this study, but then decreased gradually [32]. Hydrolysis was the rate-limiting step in anaerobic digestion. As hydrolysis progressed, leachate production increased and exceeded the water capacity of soil. Then, leachate was discharged to the outside of lysimeters and the leachate remaining in the soil was converted to methane [33-35]. Therefore, the TOC removed in all three lysimeters was mainly converted to mainly leachate. The degradation efficiency of carcasses in Lysimeter 3 was higher than those of Lysimeters 1 and 2. It revealed that the biodegradation of livestock carcasses in Lysimeter 3 increased due to anaerobic sludge addition and increased water content.

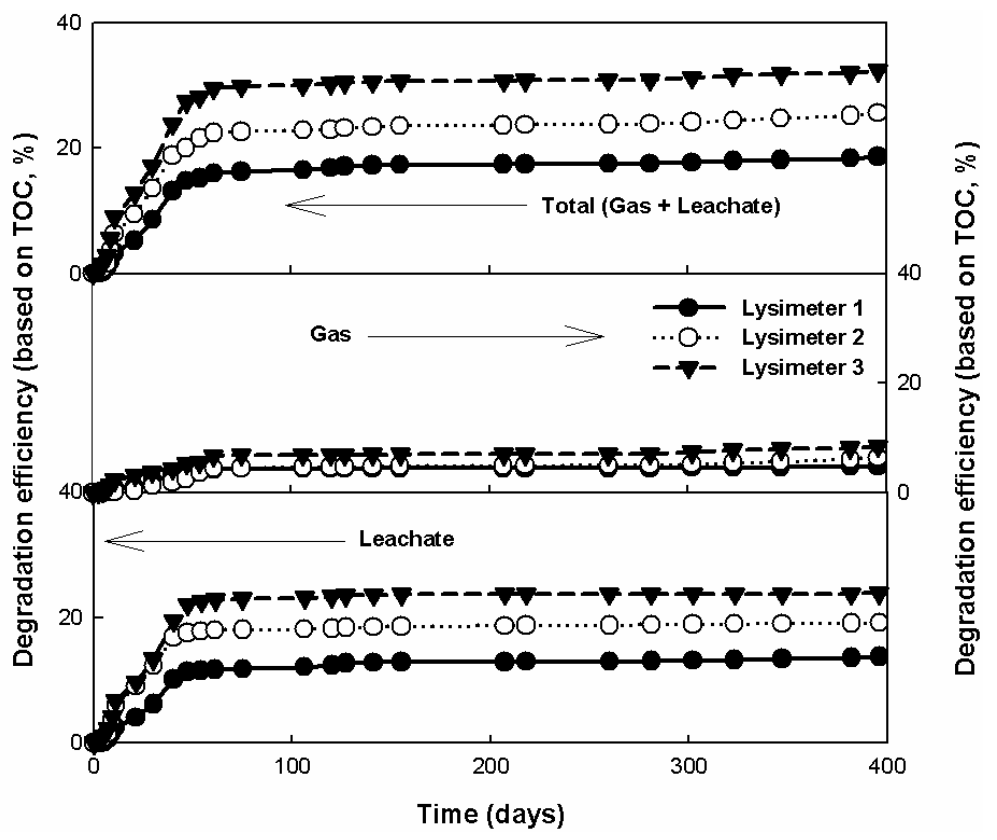

Figure 6. Degradation efficiencies based on TOC of carcasses in Lysimeters 1, 2 and 3 with time.

However, the ratio of TOC in gas produced the Lysimeter 3 was higher than other lysimeters. The major composition of the gas are carbon dioxide and methane, which were typical greenhouse gas (GHG) that cause climate change. The global warming potential (GWP) of methane, which has radiative forcing value of $0.48 \mathrm{~W} / \mathrm{m}^{2}$, is higher following carbon dioxide [33-35]. By addition of anaerobic sludge and increased water content, the biodegradation of livestock carcasses can be accelerated. However, the atmospheric environment can be affected by the GHG production from the burial sites. 
It is necessary to take measures to reduce pollution of the atmospheric environment or to utilize it as energy, considering the potential of methane production.

\subsection{Bacteria and Archaea Communities in Lysimeters}

Figure 7 illustrates the relative abundance of the bacteria and archaea communities at the phylum and genus levels, respectively. The majority of sequences from all three lysimeters were assigned to the phyla Proteobacteria, Firmicutes, Bacteroidetes, and Actinobacteria. In Lysimeter 1, Proteobacteria were predominant and accounted for $79.9 \%$ during operation. Proteobacteria and Firmicutes were predominant in Lysimeter 2 with the addition of anaerobic sludge, while Firmicutes and Bacteoidetes were predominant in Lysimeter 3 with anaerobic sludge addition and increased water content. Proteobacteria include a wide variety of pathogens including E. coli, and were founded in animal large intestines. In Lysimeter 1, Moraxellaceae (phylum Proteobacteria) were the most predominant class with an abundance of $39.3 \%$.
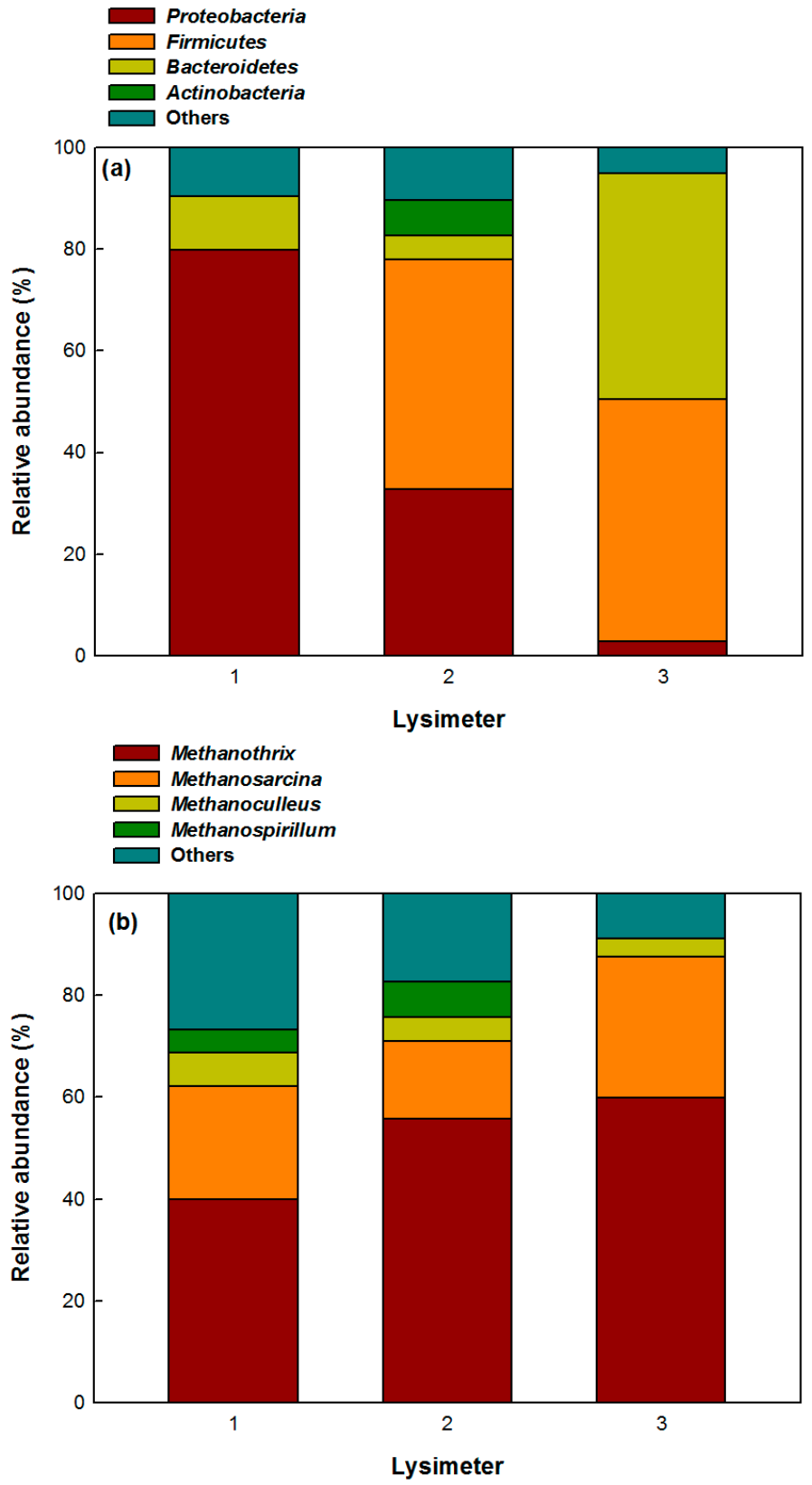

Figure 7. Taxonomic compositions of bacteria (a) and archaea (b) communities in Lysimeters 1, 2, and 3. 
Firmicutes were detected in Lysimeter 2 and 3, including the class Clostridia. Clostridia (phylum Firmicutes) are capable of performing diverse fermentation pathways in anaerobic condition. Apart from their role in hydrolysis and acidogenesis, they are involved in acetogenesis and syntrophic acetate oxidation [36,37]. Clostridia were the most predominant class in Lysimeters 2 and 3 with an abundance of $23.1 \%$ and $25.3 \%$, respectively. Bacteroidetes was mainly founded in anaerobic digestion and resistant to adverse environmental conditions such as low $\mathrm{pH}$ and temperature $[17,38]$.

If pathogens in leachate flow into surface water and/or groundwater, they can adversely affect the food of humans and animals and may cause the transmission of disease [39]. As result of this study, the relative abundances of bacteria communities including pathogens were reduced by changing operating conditions of burial sites. This could reduce the impact on natural ecosystems including humans.

According to the results of archaea community analysis, Methanothrix, Methanosaricina, Methanoculleus, and Methanosprillum were detected in all three lysimeters. The genus Methanothrix was an acetoclastic methanogen and the most predominant genus in Lysimeters 1, 2 and 3 with an abundance of $39.9 \%, 55.9 \%$ and $66.9 \%$, respectively. The genus Methanoculleus and Methanosprillum were the hydrogenotrophic methanogens, but their abundances in all three lysimeters were low $(<15 \%)$. The genus Methanosaricina, whose metabolic features are diverse, include both acetotrophic and hydrogenotrophic pathways, and its abundances in Lysimeters 1, 2 and 3 were $12.3 \%, 15.2 \%$ and 27.6\%, respectively. The relative abundances of Methanothrix and Methanosaricina in Lysimeter 3 with anaerobic sludge addition and increased water content were higher than those in other lysimeters. The relative abundances of Methanoculleus and Methanosprillum in Lysimeters 1 and 2 were higher than that in Lysimeter 3. Previous studies reported that the predominance of hydrogenotrophic methanogens such as Methanoculleus and Methanosprillum was found under stress conditions, and that it might be related to its tolerance of high ammonia concentrations $[38,40,41]$.

\section{Conclusions}

This study was performed to investigate the characteristics of pollutants and microbial communities obtained from burial sites using simulated lysimeters and to evaluate the effects of anaerobic sludge addition and increased water content on the biodegradation of livestock carcasses. In summary, this study demonstrated that the addition of anaerobic sludge to Lysimeter 2 influenced bacteria communities, involved in hydrolysis and acidogenesis, such as Clostridia, and increased the leachate production rate. Moreover, the increase of water content in Lysimeter 3 with anaerobic sludge addition resulted in the increased relative abundance of methanogens and the enhanced maximum methane production rate. Thus, the degradation efficiency of Lysimeter 3 was higher than those of other lysimeters.

Acknowledgments: This research was financially supported by the Ministry of Environment via a project entitled "The Geo-Advanced Innovative Action (GAIA) Plan for Soil and Underwater Pollution" in South Korea.

Author Contributions: J.M. and C.Y. conceived and designed the experiments; J.M. performed the experiments; J.M., S.K. and C.Y. analyzed the data and wrote the paper.

Conflicts of Interest: The authors declare no conflict of interest.

\section{References}

1. Ministry of Agriculture Food and Rural Affairs (MAFRA). Foot-and-Mouth Disease Standard Operating Procedure (SOP); University States Department of Agriculture: Riverdale, MA, USA, 2012.

2. Choi, N.C.; Choi, E.J.; Kim, B.J.; Kim, S.B.; Park, J.A.; Park, C.Y. Characterization of water quality and the aerobic bacterial population in leachate derived from animal carcass disposal. J. Eng. Geol. 2013, 23, 37-46. [CrossRef]

3. Cho, P.H. Detection of foot-and-mouth disease virus and coxsakievirus in the soil and leachate of modeled carcass burial sites. Korean J. Vet. Serv. 2012, 35, 255-261. [CrossRef] 
4. Gwyther, C.L.; Williams, A.P.; Golyshin, P.N.; Edward-Jones, G.; Jones, D.L. The environmental and biosecurity characteristics of livestock carcass disposal methods: A review. Waste Manag. 2011, 31, 767-778. [CrossRef] [PubMed]

5. Kim, M.H.; Kim, G.H. Cost analysis for the carcass burial construction. Korean Soc. Soil Groundw. Environ. 2013, 18, 137-147. [CrossRef]

6. Pratt, D.L. Environmental Impact of Livestock Mortalities Burial. Master's Dissertation, The University of Saskatchewan, Saskatoon, SK, Canada, 2009.

7. Kang, M.A.; An, Y.S. Behavior of refractory organic matter in leachate from landfill contaminated by foot-and-mouth disease. J. Eng. Geol. 2013, 23, 427-434. [CrossRef]

8. Park, J.A.; Choi, N.C.; Kim, S.B. Analysis of microbial communities in animal carcass disposal soils. J. Korean Soc. Environ. Eng. 2013, 25, 503-508. [CrossRef]

9. Yuan, Q.; Samuel, E.S.; Bartelt-Hunt, S.L. Methane and carbon dioxide production from simulated anaerobic degradation of cattle carcasses. Waste Manag. 2012, 32, 939-943. [CrossRef] [PubMed]

10. Yuan, Q.; Snow, D.D.; Bartelt-Hunt, S.L. Potential water quality impacts originating from land burial of cattle carcasses. Sci. Total Environ. 2013, 456-457, 246-253. [CrossRef] [PubMed]

11. Kang, M.E.; Kim, M.S.; Choi, B.W.; Sohn, H.Y. Organic matter analysis and physicochemical properties of leachate from a foot-and-mouth disease landfill site. Korean J. Microbiol. Biotechnol. 2012, 40, 128-134. [CrossRef]

12. Vinten, A.; Smith, H.; Watson, C.; Fenlon, D.; Ritchie, R. Assessment of Risks of Water Contamination with E. coli, Salmonella and Cryptosporidium from Burial of Animal Carcasses Using Artificially Drained Field Burial Plots; Macaulay Institute: Aberdeen, UK, 2008.

13. Kim, J.K.; Han, S.K.; Kim, G.H.; Kim, J.T.; Lee, C.Y. Biodegradation characteristics of organic matters in swine carcasses under different initial operating conditions of simulated anaerobic lysimeter. J. Mater. Cycles Waste Manag. 2017, 19, 118-123. [CrossRef]

14. Eaton, A.D.; Clesceri, L.S.; Rice, E.W.; Greenberg, A.E.; Franson, M.A.H. Standard Methods for the Examination of Water and Wastewater, 21th ed.; American Public Health Association: Washington, DC, USA, 2005.

15. Kafle, G.K.; Kim, S.H.; Sung, K.I. Ensiling of fish industry waste for biogas production: A lab scale evaluation of biochemical methane potential (BMP) and kinetics. Bioresour. Technol. 2013, 127, 326-336. [CrossRef] [PubMed]

16. Lee, S.H.; Kang, H.J.; Lee, Y.H.; Lee, T.J.; Han, K.; Choi, Y.; Park, H.D. Monitoring bacterial community structure and variability in time scale in full-scale anaerobic digesters. J. Environ. Monitor. 2012, 14, 1893-1905. [CrossRef] [PubMed]

17. Li, L.; He, Q.; Ma, Y.; Wang, X.; Peng, W. A mesophilic anaerobic digester for treating food waste: Process stability and microbial community analysis using pyrosequencing. Microb. Cell Fact. 2016, 15, 65. [CrossRef] [PubMed]

18. Rafizul, I.M.; Howlader, M.K.; Alamgir, M. Construction and evaluation of simulated pilot scale landfill lysimeter in Bangladesh. Waste Manag. 2012, 32, 2068-2079. [CrossRef] [PubMed]

19. Sanphoti, N.; Towprayoon, S.; Chaiprasert, P.; Nopharatana, A. The effects of leachate recirculation with supplemental water addition on methane production and waste decomposition in a simulated tropical landfill. J. Environ. Manag. 2006, 81, 27-35. [CrossRef] [PubMed]

20. Christensen, T.H.; Cossu, R.; Stegmann, R. Sanitary Landfilling: Process, Technology and Environmental Impacts; Academic Press: London, UK, 1989.

21. Tatsi, A.A.; Zouboulis, A.I. A field investigation of the quantity and quality of leachate from a municipal solid waste landfill in a Mediterranean climate (Thessaloniki, Greece). Adv. Environ. Res. 2002, 6, 207-219. [CrossRef]

22. Clement, B. Physico-chemical characteristics of 25 French landfill leachate. In Proceedings of the Sardinia 95-5th International Landfill Symposium, Cagliari, Italy, 2-6 October 1995; pp. 315-325.

23. Chen, P.H. Assessment of leachates from sanitary landfill: Impact of age, rainfall and treatment. Environ. Int. 1996, 22, 225-237. [CrossRef]

24. Carter, D.O.; Yellowlees, D.; Tibbett, M. Cadaver decomposition in terrestrial ecosystems. Naturwissenschaften 2007, 94, 12-24. [CrossRef] [PubMed]

25. Skujins, J.J.; McLaren, A.D. Enzyme reaction rates at limited water activities. Science 1967, 158, $1569-1570$. [CrossRef] [PubMed] 
26. Khanal, S.K. Anaerobic Biotechnology for Bioenergy Production; Wiley-Blackwell: Ames, IA, USA, 2008.

27. Luo, K.; Yang, Q.; Li, X.; Yang, G.; Liu, Y.; Wang, D.; Zheng, W.; Zeng, G. Hydrolysis kinetics in anaerobic digestion of waste activated sludge enhanced by $\alpha$-amylase. Biochem. Eng. J. 2012, 62, 17-21. [CrossRef]

28. Mou, Z.; Schutz, C.; Kjeldsen, P. Evaluating the methane generation rate constant (k value) of low-organic waste at Danish landfills. Waste Manag. 2015, 35, 170-176. [CrossRef] [PubMed]

29. Aghdam, E.F.; Scheutz, C.; Kjeldsen, P. Assessment of methane production from shredder waste in landfills: The influence of temperature, moisture and metals. Waste Manag. 2016, in press. [CrossRef]

30. Li, C.; Mőrtelmaier, C.; Winter, J.; Gallert, C. Effect of moisture of municipal biowaste on start-up and efficiency of mesophilic and thermophilic dry anaerobic digestion. Bioresour. Technol. 2014, 168, $23-32$. [CrossRef] [PubMed]

31. Fujishima, S.; Miyahara, T.; Noike, T. Effect of moisture content on anaerobic digestion of dewatered sludge: Ammonia inhibition to carbohydrate removal and methane production. Water Sci. Technol. 2000, 41, 119-127. [PubMed]

32. Matsufuji, Y.; Tachifuji, A.; Matsugu, H. Maa Balance in Anaerobic and Semiaerobic Landfill Type, Sustainable Landfilling; Cossu, R., van der Sloot, H., Eds.; International Waste Working Group: Padova, Italy, 2014; pp. 106-117.

33. Jiang, X.; Mira, D.; Cluff, D.L. The combustion mitigation of methane as a non-CO ${ }^{2}$ greenhouse gas. Prog. Energy Combust. Sci. 2016, in press. [CrossRef]

34. Intergovernmental Panel on Climate Change (IPCC). Climate Change 2007: The Physical Science Basis; Cambridge University Press: Cambridge, UK, 2007.

35. Mosier, A.R.; Duxbury, J.M.; Heinemeyer, O.; Minami, K.; Johnson, D.E. Mitigating agricultural emissions of methane. Clim. Chang. 1998, 40, 39-80. [CrossRef]

36. Wirth, R.; Kovăcs, E.; Marŏti, G.; Bagi, Z.; Răkhely, G.; Kovăcs, K.L. Characterization of a biogas-producing microbial community by short-read next generation DNA sequencing. Biotechnol. Biofuels 2012, 5, 41. [CrossRef] [PubMed]

37. Ziganshin, A.M.; Liebetrau, J.; Prorter, J.; Kleinsteuber, S. Microbial community structure and dynamics during anaerobic digestion of various agricultural waste materials. Bioenergy Biofuels 2013, 97, 5161-5174. [CrossRef] [PubMed]

38. Goux, X.; Calusinka, M.; Lemaigre, S.; Marynowska, M.; Klocke, M.; Udelhoven, T.; Benizri, E.; Delfosse, P. Microbial community dynamics in replicate anaerobic digesters exposed sequentially to increasing organic loading rate, acidosis, and process recovery. Biotechnol. Biofuels 2013, 8, 122. [CrossRef] [PubMed]

39. National Agricultural Biosecurity Centre. Carcass Disposal: A Comprehensive Review; Report Written for the USDA Animal and Plant Health Inspection Service; Kansas State University: Manhattan, KS, USA, 2004.

40. Franke-Whittle, I.H.; Walter, A.; Ebner, C.; Insam, H. Investigation into the effect of high concentration of volatile fatty acids in anaerobic digestion on methanogenic communities. Waste Manag. 2014, 34, 2080-2089. [CrossRef] [PubMed]

41. Schlúter, A.; Bekel, T.; Diaz, N.N.; Dondrup, M.; Eichelaub, R.; Gartemann, K.H.; Krahn, I.; Krause, L.; Krőmeke, H.; Kruse, O.; et al. The metagenome of a biogas-producing microbial community of a production-scale biogas plant fermenter analysed by the 454-pyrosequencing technology. J. Biotechnol. 2008, 136, 77-90. [CrossRef] [PubMed]

(C) 2017 by the authors. Licensee MDPI, Basel, Switzerland. This article is an open access article distributed under the terms and conditions of the Creative Commons Attribution (CC BY) license (http:/ / creativecommons.org/licenses/by/4.0/). 